\title{
COVID PANDEMIC AND FOREIGN DIRECT INVESTMENTS IN THE POLISH ECONOMY
}

\author{
Katarzyna WITCZYŃSKA \\ Wroclaw University, Institute of Economic Sciences; katarzyna.witczynska@uwr.edu.wroc.pl, \\ ORCID: 0000-0002-8021-3967
}

\begin{abstract}
Purpose: The paper presents the issues related to the development of foreign direct investments during covid pandemic time.

Design/methodology/approach: The study used world-bank reports from trading economics portal and Ernst and Young study.

Findings: The aim of the article is to present the changes in the inflow of foreign direct investment in the face of the global Covid 19 coronavirus pandemic to Poland.

Originality/value: The publication presents the results of research conducted on the basis trading economics portal and Ernst and Young study. on the basis of the literature analysis, it is possible to that will have an impact on direct and foreign investments: rapid technological development aimed at reducing costs and expansion to new customers, regional commitment to counteracting climate change and commitment to sustainable development, new proportions resulting from the reorganization of the supply chain (reshoring, nearshoring, offshoring).
\end{abstract}

Keywords: global value chain, supply chain, direct investment, international investment climate, COVID-19.

Category of the paper: Research paper.

\section{Introduction}

Foreign direct investment is a very important part of the Polish economy. After accession, Poland became one of the major countries receiving FDI in Europe. Thanks to foreign investors who are guided by specific motives, such as the desire to reach new customers, win a new market, increase profits or access to resources from a given region, the Polish economy has revived and developed. The available statistics show that the amount of FDI in Poland is constantly increasing. International enterprises see great potential in the size of the Polish market, good legal regulations, low employee costs, and in many cases very well-trained staff in the area of the latest technologies and research. Taking into account the above motives, development and good prospects for the Polish economy are expected. The current difficult 
situation in Poland and around the world strongly affects FDI. Many enterprises suspended their ventures in 2020 and announced that they would be phasing out more in the coming years. The available analyzes indicate a weakening and inflow of direct investments in Poland. However, the coronavirus has forced many companies to think and introduce positive changes on many levels, such as in the supply chain sector.

\section{Foreign direct investment}

Direct foreign investment we call investments in which foreign investors have the so-called persistent receipts in a foreign company. There is a certain threshold value that distinguishes FDI from portfolio investments and is $10 \%$ of common shares or $10 \%$ of voting rights general meetings. Transfers have a huge impact on the importance of the world economy capital in the form of direct investment. FDI is a unique form of investment referred to according to the investment location criterion, i.e. investments are made in another country of residence investor. We divide capital transfers into funds transfers as well specific investment goods. The main investment motives are: income and control. The intention to control gives the investor the ability to influence a foreign enterprise in which that investor holds a share of the capital. On the motive control is affected by the entire transferred package of production factors. In addition to capital goods and labor forces are also transfers of intangible factors such as: marketing and technological know-how, organization and management methods, and research experience development (Jaworek, 2006).

Activities, decisions and directions of foreign activity are not the result of just one motive, but of their entire group. By following many motives, investors maximize profits. Based on the motives for creating new enterprises abroad, we distinguish a classification criterion that distinguishes four forms of foreign investments: (1) resource-oriented (resource seeking), (2) market-oriented, (3) efficiency-seeking, (4) strategic asset seeking.

The above forms can also be divided into defensive and offensive investment strategy. In an offensive strategy, it is the investor who independently starts the investment in the target achieving your goal. The latter defensive strategy, in turn, relates to reaction on market behavior or the policy of the host government. A defensive response is essential to defend your area in the market. These strategies get mixed up often (Rymarczyk, 2004).

Due to foreign investment, an increase in the investment resources of the host country can be noticed, which translates into faster economic growth. Direct economic investments also offer the possibility to modernize production resources, improve technology and improve management as well as increase company efficiency and increasing the quality of manufactured products. General expectations of the host country (Karaszewski, 2005) are powering the weak economy of the host country resulting from low savings internal and technological development 
of the economy and the introduction of innovative methods management, and export development.

In addition to financial capital, foreign investors transfer modern management, technology and intellectual capital. This takes the form of patents, technological solutions, licenses, educational activities, technical assistance or scientific exchange. Thanks to the flow capital also includes the flow of knowledge, the flow of people, technology, know-how and other development factors. In broad terms, the flow of technology is the transfer of technical knowledge and know-how how to apply such technology in production. Transfer concerns the development, acquisition, adaptation and use of knowledge (Umiński, 2002).

\section{FDI in Figures in Poland bevor COVID}

Properly functioning supply chains increase the value of international trade. Global logistics companies ensure the flow of goods between countries and are an essential element in the functioning of this phenomenon. It can be seen that prior to the pandemic, the value of global trade has increased in recent years. In 2019, this value oscillated at a similar level. In turn, at the turn of March and May 2020, there was a massive decrease by approx. $17.7 \%$. This is shown in figure 1. According to the study by Ernst and Young 2019 was one of the best years in Europe in terms of the number of planned foreign direct investments. EY's analysis shows that 6,412 FDI projects were announced in Europe last year, an increase of $0.9 \%$ compared to 2018. A significant increase in foreign investment and the first place in terms of the number of investments was taken by France, which recorded 1197 newly announced FDI (+17\% y/y). The next steps on the podium were: Great Britain with 1,109 investments $(+5 \% \mathrm{y} / \mathrm{y})$ and Germany, which recorded a 3\% decrease in the number of FDI to 1,109. Poland, with 200 new ventures planned by foreign investors, was ranked 7th in Europe. The EY study showed differences between countries and industries in the impact of COVID-19 on the implementation of previously planned investments. In competitive economies and where projects related to the construction of shared service centers, investment in the IT sector or the construction of research and development facilities, almost $80 \%$ of planned investments are implemented. This is significantly higher than the European average of $65 \%$. Among the countries with a higher investment implementation rate, EY includes Poland, Ireland and Portugal. The data for 2019 is unfortunately a story that will not repeat itself for a long time. Despite the fear of a hard Brexit and tensions in world trade, Europe managed to achieve a symbolic, but still increase in planned FDI. The outlook for the coming years is not good, and without foreign investments, returning to the path of economic growth may be more difficult. Poland figures among the most attractive countries in Europe in terms of FDI. According to UNCTAD's 2020 World Investment Report, FDI inflows to Poland remain stable in 2019, reaching USD 
13,2 billion, slightly up from USD 13,9 billion. The total stocks of investments in the country stood at USD 236,5 billion in 2019, an increase of 26\% when compared to 2010 level. Poland is the first largest recipient of FDI inflows in Central Europe. Most stocks are held by Germany, the Netherlands, Luxembourg and France, with investments directed mainly to the manufacturing, financial and insurance activities, and wholesale and retail sectors. In addition, this past year FDI data showed a high percentage of investors coming from China and South Korea.

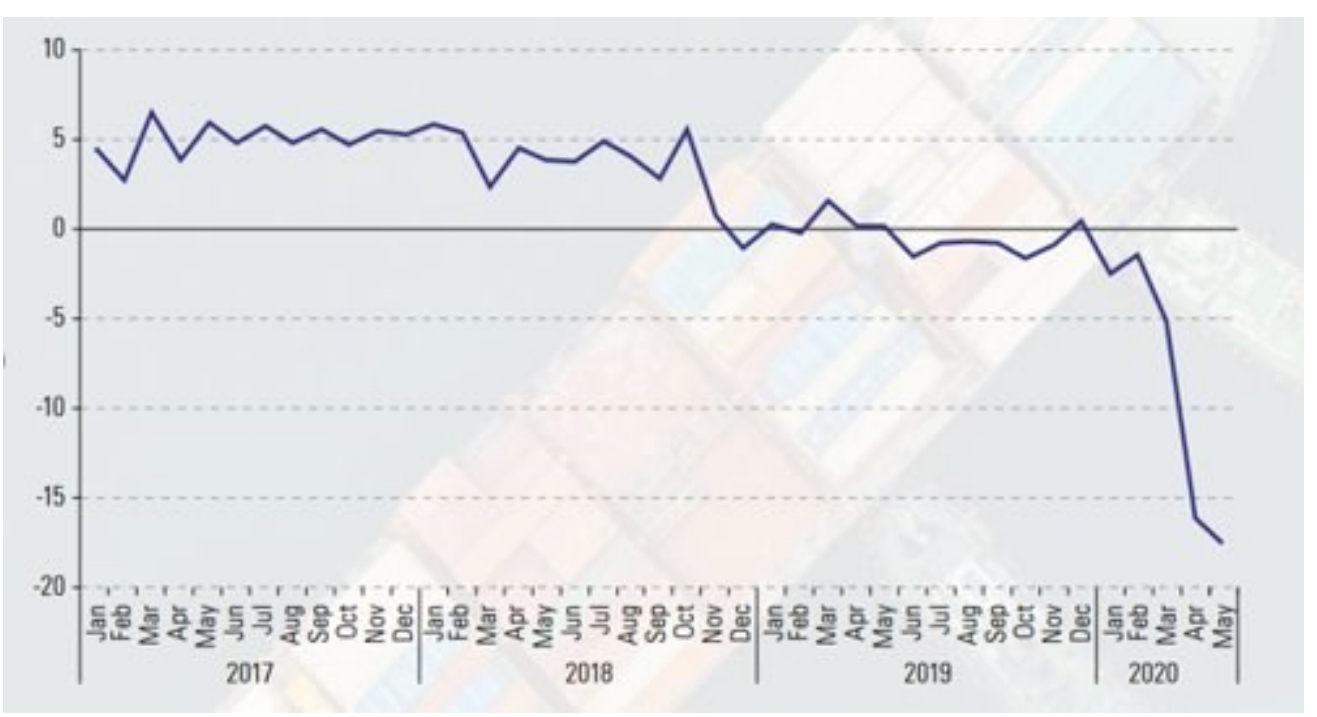

Figure 1. Monthly changes in the value of global trade in 2017-2020 (percent)s (source: Economic Commission for Latin America and the Caribbean (ECLAC), on the basis of Netherlands Bureau of Economic Policy Analysis (CPB), World Trade Monitor [online database] https://www.cpb.nl/en/ worldtrademonit, 2020).

Table1.

0 Top European FDI destination countries, (source EY)

\begin{tabular}{|l|l|l|l|l|l|}
\hline Rank & Country & $\mathbf{2 0 1 7}$ & $\mathbf{2 0 1 8}$ & Change 2017/18 & Market share (2018) \\
\hline 1 & UK & 1,205 & 1,054 & $-13 \% \downarrow$ & $17 \%$ \\
\hline 2 & France & 1,019 & 1,027 & $1 \% \uparrow$ & $16 \%$ \\
\hline 3 & Germany & 1,124 & 973 & $-13 \% \downarrow$ & $15 \%$ \\
\hline 4 & Spain & 237 & 314 & $32 \% \uparrow$ & $5 \%$ \\
\hline 5 & Belgium & 215 & 278 & $29 \% \uparrow$ & $4 \%$ \\
\hline $\mathbf{6}$ & Poland & $\mathbf{1 9 7}$ & $\mathbf{2 7 2}$ & $\mathbf{3 8 \%} \uparrow$ & $\mathbf{4 \%}$ \\
\hline 7 & Turkey & 229 & 261 & $14 \% \uparrow$ & $4 \%$ \\
\hline 8 & Netherlands & 339 & 229 & & $4 \%$ \\
\hline 9 & Russia & 238 & 211 & $11 \% \downarrow$ & $3 \%$ \\
\hline 10 & Ireland & 135 & 205 & $52 \% \uparrow$ & $3 \%$ \\
\hline
\end{tabular}

Central and Southeast Europe (CSE) is now considered the second-most attractive region for investment. Five years ago, it ranked only fourth. Within CSE Poland is an unquestionable leader and the $6^{\text {th }}$ most attractive country in Europe. Investment in Poland surged 38 per cent to 272 FDI projects in 2018. Poland's main assets are its strategic position, a large population, its European Union membership, economic stability, cheap skilled labour costs and a fiscal system attractive to businesses. Furthermore, Poland has a number of dynamic Special 
Economic Zones, and the government founded the Polish Investment and Trade Agency (PAIZ) to improve conditions for FDI. However, Polish law limits foreign ownership of companies in selected strategic sectors, and restricts acquisition of real estate, especially agricultural and forest land. Furthermore, the current conservative government's willingness to increase the percentage of domestic ownership in certain industries (including banking and retail, which are currently dominated by foreign companies) negatively contributed to foreign investment. Overall, the Polish business climate is good and the World Bank ranks Poland 40th out of 190 countries in its 2020 Doing Business ranking, losing 7 positions compared to the previous year. As can be seen from the chart above Foreign direct investment in Poland increased by EUR 209504.80 million in 2019. The virus that appeared in the second half of December 2019 and quickly spread throughout Asia, Europe and North America. Currently, almost every country in the world has reported cases of patients infected with this virus ( $\mathrm{Li}, 2020)$, and this undoubtedly affects FDI. According to the recently published report by Ernst and Young Unfortunately, due to the recent events in the world and in Poland, and more specifically with the COVID-19 virus, according to a recent analysis prepared by EY, the attractiveness of direct investments will decrease. According to the report, 6,412 FDI are planned in Europe in 2019. However, the current difficult situation caused them to decline. EY estimates that projects planned in the previous year were 65 percent complete, 25 percent delayed and 10 percent canceled. According to the Ernst and Young study from 2020, as many as 83 percent of managers in the survey assumed reorganization of the supply chain and the transfer of selected production stages to new member states in a European country. The current situation has led to many changes in the supply chain sector. Experts from C.H. Robinson analyzed the last period and made the following conclusions. The first is the visibility of loads, which manifests itself in an increased need for visibility and transparency of the flow. As a result, companies gain a greater understanding of inventory and sales, supply networks, strategic locations of suppliers and their goods, inventory levels, and customer preferences. Thanks to the latest technology, appropriate tools and careful observation, companies will be able to develop more effective operating strategies, provide more efficient service and flow of goods exchange. Such efficient organization and activities will lead to lower costs. Such actions also lead to the development of a good risk management strategy in the event of a crisis. Detailed knowledge at every stage of the supply chain enables the development of efficient solutions. Another important element was the number of available suppliers. The pandemic has shown us that relying on only one supplier for financial and logistical reasons is not enough in the event of a pandemic. According to the analysts from the study, it is important to have different sources of obtaining goods from different geographic locations checked. Such conservative measures will facilitate the diversification of the supply chain. The fourth conclusion concerns efficient customer service. The pandemic has shown us how important the latest technology, applications and online shopping are. During this difficult period, we were forced to buy online in most cases. For this reason, experts propose to take care of and improve websites, mobile applications and customer 
service in order to ensure the best quality of their services in crisis situations. The last conclusion relates to the 4.0 chain. It is based on the combination of the latest technology with available machines, information transfer in the cloud as well as analytics and artificial intelligence. Thanks to this type of solutions, enterprises will gain accurate knowledge of the current demand, quick response to changing conditions and checking potential scenarios. However, Europe's outlook after COVID-19 is pessimistic: 49\% of surveyed managers according to Ernst and Young believe that the continent is threatened with less or severely diminished attractiveness as a location for foreign investment.

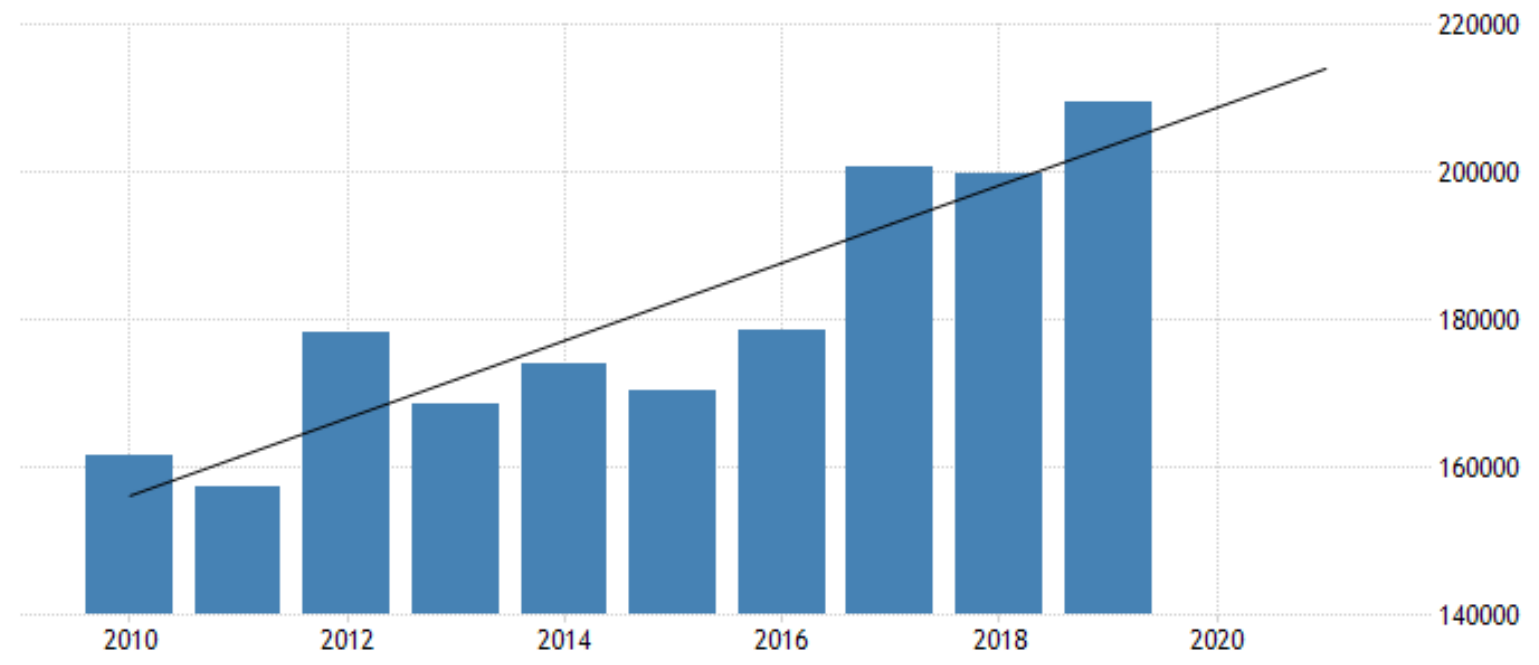

Figure 2. Poland Foreign Direct Investment 2010-2019 (source: https://tradingeconomics.com/poland/ foreign-direct-investment).

Poland's position on the world map of foreign direct investment is not particularly significant. Regardless of whether you count in dollars or zlotys, the scale of foreign direct investment in our country is less than 1 percent. global cross-border investment. The importance of our country as a place for investment capital may, however, increase if UNCTAD's predictions prove that large European companies will - after the experiences of the pandemic look for or create new suppliers, perhaps not as cheap as at the end of the world, but much closer geographically. Poland can benefit from this. It turns out that, compared to other countries in Europe and the world, Poland is unique. "FDi Intelligence", operating within the Financial Times, informed that Poland is a leader in Europe in terms of increasing the inflow of foreign direct investment (FDI). In addition, the European Commission forecasts that the recession in Poland is to be the shallowest in the entire EU - in 2020 Poland's GDP will shrink by only 4.6 percent. In turn, in the published forecasts, as part of the June edition of the "Global Economic Prospects" report - the World Bank forecasts a decline in Poland's GDP in 2020 at the level of 4.2 percent, emphasizing that the fiscal situation in Poland is better than in other countries of the region, also thanks to "Diversification and competitiveness". 


\section{Summary}

Foreign direct investment in Poland increased by EUR 209504.80 million in 2019. The current difficult situation in Poland and around the world has a strong impact on FDI. Many companies have suspended their ventures in 2020 and have announced that they will be phasing out more in the coming years. The available analyzes indicate a weakening and inflow of direct investments in Poland. However, the coronavirus has forced many companies to think and introduce positive changes on many levels, such as in the supply chain sector.

The current difficult situation that prevails in Poland and around the world in connection with COVIDEM-19 strongly affects FDI and decisions taken at the highest management levels. Many enterprises suspended or canceled their projects in 2020 and announced the withdrawal of further ones in the following years (25\% were withdrawn and $10 \%$ were canceled from planned FDI in 2020). The available analyzes indicate a weakening and an influx direct investments in Poland in the coming time, and the newly created threats also influenced the changes in the supply chain. So far, foreign direct investment in Poland has had going well however the COVID-19 pandemic has led to many withdrawals, cancellations, changes or difficult decisions. We are unable to determine how long the pandemic and the current coronavirus last will persist in Poland, Europe and the world.

\section{References}

1. https://tradingeconomics.com/poland/foreign-direct-investment, 20.11.2020.

2. https://www.ey.com/pl_pl/news/2020/05/atrakcyjnosc-inwestycyjna-europy, 10.11.2020.

3. https://www.wsparcie.sse.lodz.pl/home/z28kmetyxhp40t6a1653hqfstcg712, 15.11.2020.

4. Jaworek, M. (2006). Bezpośrednie inwestycje zagraniczne w prywatyzacji Polskiej gospodarki. Toruń: Wyd. Dom Organizatora.

5. Karaszewski, W. (2005). Bezpośrednie inwestycje zagraniczne $w$ podnoszeniu konkurencyjności Polskiej gospodarki. Toruń: Wyd. Dom Organizatora.

6. Li, Q, Guan, X., Wu, P., Wang, X., Zhou, L., Tong, Y. et al. (2020). Early transmission dynamics in Wuhan, China, of novel coronavirus-infected pneumonia. N. Engl. J. Med. 2020 Jan 29 [Epub ahead of print]. Available from: https://www.nejm.org/doi/ 10.1056/NEJMoa2001316.

7. Rymarczyk, J. (2004). Internacjonalizacja i globalizacja przedsiębiorstwa. Warszawa: PWE.

8. Umiński, S. (2002). Znaczenie zagranicznych inwestycji bezpośrednich dla transferu technologii do Polski. Gdańsk: Uniwersytet Gdański. 